\title{
Women Do the Job: The Reasons to Set Quota for Women on Boards
}

\author{
Sara De Masi ${ }^{1}$, Agnieszka Słomka-Gołębiowska ${ }^{2} \&$ Andrea Paci $^{1}$ \\ ${ }^{1}$ Department of Economics and Management, University of Florence, Florence, Italy \\ ${ }^{2}$ Department of International Comparative Studies, Warsaw School of Economics, Warsaw, Poland \\ Correspondence: Sara De Masi, Department of Economics and Management, University of Florence, via delle \\ Pandette 9, Florence, Italy. E-mail: sara.demasi@unifi.it
}

Received: September 22, 2018

doi:10.5539/ijbm.v13n12p167

\author{
Accepted: November 2, 2018 \\ Online Published: November 15, 2018 \\ URL: https://doi.org/10.5539/ijbm.v13n12p167
}

\begin{abstract}
In 2012 Italy introduced quota to increase the number of women on corporate boards. The aim of our research is to shed more lights on how women on boards, after the enforcement of quota law, improve the board functions and the board structure. Our study focuses on all Italian FTSE MIB companies from 2008 to 2015. Italy is a country where the percentage of female directors was very low before quota. Female directors, when present, were linked through a family connection to the controlling shareholder. Our research demonstrates that a higher percentage of women on boards, after the quota, leads to a higher board members attendance and more board meetings, thus a better board monitoring. We document that, after quota, one more women to the board results in increasing the board involvement in strategy and the independence of audit committee. Our findings provide empirical support on the effectiveness of female directors, suggesting important implications of the quota legislation on the "type" of women elected.
\end{abstract}

Keywords: board of directors, gender diversity, quota, board functions, board structure

\section{Introduction}

In the last years, many countries in Europe have introduced the quota regulation that aims to increase the number of women on corporate boards. Twelve Member States have introduced quota: five countries (France, Belgium, Italy Germany and Portugal) have sanctions for non-compliance; two countries (the Netherlands and Spain) have lunched quotas without sanctions and Austria, Denmark, Finland, Greece and Slovenia have regulation only for state-owned companies.

The main reason behind this promotion of gender diversity at echelon is that women on corporate boards improve corporate governance as well as enhanced company performance (European Commission, 2012). However, in corporate governance literature, a number of studies, which focuses on the value of having women on boards looking at the association between the ratio of women on boards and the firm financial performance, has lead to inconclusive results (see the survey Kirsch, 2017).

The aim of this paper is to shed more lights about the relationship between gender diversity and board functions and board structure. In particular, the paper looks whether gender diversity, imposed by quotas, affects: (1) the board functions i.e. the company's commitment towards following best practice corporate governance principles related to board functions; (2) the board structure i.e. the company's commitment towards following best practice related to a well balanced membership, in terms of diverse, experienced and independent board members.

The paper contributes to the research literature in three ways. First, we would like to add up to the stream of research on the female directors and board governance. We also disaggregate those measures of board governance into sub-measures to better understand, which board items are affected by women.

Second, there are few studies how regulation on quotas has affected the relationship between women on boards and board outcomes. Prior studies show the effect of quota on firm financial performance and investors reactions to the news that firms will be subjected to regulation. We would like to feel the gap and shed lights whether gender quotas for boards are sufficient regulatory change to achieve better corporate governance. The results have significant implications for regulators that might want to enforce quotas or evaluate their consequences.

Third, our study focuses on FTSE Italian companies. In Italy, quota has been introduced in 2012. To date, the majority of studies on the effect of regulation on quotas are concerned with the Norwegian case. The Nordic 
countries, where there is lower gender inequality measured by the UN index, have a long history of social support for gender equality. In such countries there is no evidence that women on boards decreases the qualifications of the board members. On the contrary, Lending \& Vahamaa (2017) report that pending quotas decreases the board expertise in the Southern European countries. Our paper aims to shed lights to the recently debated issue whether gender quotas decreasing board expertise and hence, caused underperforming boards.

The remainder of this paper is organized as follows: Section 2 presents gender-related institutional background in Italy, literature review and develops the hypotheses. Section 3 describes our research design and methodology. Section 4 explains the results of our research. In the last section, conclusions as well as implications for policy makers are drawn and presented.

\section{Institutional Background, Literature Review and Hypotheses Development}

\subsection{Institutional Background in Italy}

Corporate governance is influenced by national institutional setting (Roe 2003; Aguilera \& Cuervo-Cazurra, 2004; Aguilera, Filatotchev, Gospel \& Jackson, 2008; Aguilera \& Jackson, 2003; Buck \& Shahrim, 2005; Minichilli, Zattoni, Nielsen \& Huse, 2012). This means that national contexts potentially exert a significant influence on the presence of women on corporate boards and on the board performance.

According to the institutional theories, there are two types of institutions: formal institutions (North, 1990; Whitley, 1992) and informal institutions (North, 1990; DiMaggio \& Powell, 1983). Among the formal institutions, legal systems, governmental policies, labor market structure and education are particularly important in understanding the participation of women on corporate boards (Grosvold \& Brammer, 2011; Grosvold, Rayton \& Brammer 2016). Among informal institutions, national culture, the role of the family and the religion play a key role in shaping the equality perception and help women to rise to the top of publicly listed companies (Grosvold, Rayton \& Brammer 2016). Research shows that the equality perception and the participation of women in corporate boards are more likely in countries (1) where women are well represented in tertiary education; (2) where women are represent largely the managerial segment of the labor market as well as the economy provides incentives on women career's advancement and (3) where governments make investments designed to support financially childcare. In Italy these institutions seem not to give strong support to women and their impact on the participation of female directors on corporate boards is insignificant. One of the primary institutions that influence the inclusion of women on executive positions, and eventually on board of directors, is the government. In particular, the national government determines the female employment opportunities, because it creates conditions that facilitate, or hinder, women to have a better balance between professional and personal life (Houseknecht \& Sastry, 1996). According to Thompson, Graham \& Lloyd (2005), in countries where governments enforce programs that support women to go back into the labor market after the child birth, the number of female managers qualified for board membership is higher than in countries without such policies. Italy has one of the longest statutory maternity leaves (22 weeks) among European Member States and parental leave is relatively generous (Pronzato 2009). Although this policy may make easier for women to manage their child birth, employers who fear long absence of their female workforce may be reluctant to hire women for responsible positions and hence they might be lacking adequate experiences for a key leadership role or top management positions. According to the European Commission, Italy has never elaborated effective policies to ease the inclusion of women into the labor market after the maternity leave: the lack of services for children and for the elderly make it hard to have a better work-family life balance (European Commission, 2016). This lack of institutional supports shapes the women's career choices and the likelihood to be appointed as a board member.

Another determining factor for the participation of women on corporate boards is the size and the structure of the labor market (Carli \& Eagly, 2011). In order to be eligible for board nomination, a female director needs to have professional experience and skills similar to those of the male directors (Singh \& Vinnicombe, 2004; Sheridan \& Milgate, 2005). This experience depends on the opportunity to women to have managerial positions. Terjesen and Singh, Terjesen, \& Vinnicombe (2008) show that in countries where women occupy a large share of executive positions, the number of female directors is higher than in countries with a low number of female top managers. In Italy the percentage of women that hold a top management position is very low. According to European Institute for Gender Equality (2017) in Italy in 2012 the percentage of women among executives was only $4 \%$. This shows that the managerial labor market for women is very limited and the employment opportunities for decision-making positions are very low.

A third institution that might explain the inclusion for women on corporate boards is the enrollment of women in the education at university level. Advanced education is an important driver for board appointments (Burke 1997; Sheridan 2001; Singh \& Vinnicombe 2004). It ensures men to view women as equals in the professional life 
(Calori, Lubatkin, Very \& Veiga 1997; Kanter 1976). This level of education is also relevant for the development of networking between college students that can help to increase the likelihood to be involved in the corporate boards (Westphal \& Stern, 2006). Prior research finds that university ties and alumni connections increase the likelihood to be appointed as a board member (Westphal \& Milton, 2000; Sheridan \& Milgate 2003). Over the last decades, Italian women have gradually caught up with men in the field of education. According to World Bank, the percentage of women in tertiary education was 55\% in 1999, 57\% in 2012 and $56 \%$ in 2016 . Although women are well represented in tertiary education, their participation in the executive positions is very limited. In 2012, only 4\% of the executives were women (European Institute for Gender Equality, 2017). This evidence suggests that women experience a glass ceiling effect and they find difficulties to be appointed as a board member even if they are well-educated as their male counterpart.

Among informal institutions, the role of the family is one of the most influential institutions for women and their career's choices (Budig, Misra, \& Boeckmann, 2012). Prior studies show that women with executive ambitions are more likely to be unmarried (Burgess \& Tharenou, 2002) and career executive aspirations are associated with a higher rate of divorce (Mathur-Helm, 2006). Between 2006 and 2015 the rate of divorce in Italy was stable (United Nations Demografic Year, 2016), suggesting that the role of the family has not changed over time. Italy is still a family-oriented country, where the value of family, and as consequence the role of the women within the family, is still playing a meaningful role in the women career's decisions.

Also religion influences the women's career preferences. Specifically, it affects the perception of gender equality (Parboteeah, Hoegl, \& Cullen 2008). In Catholic countries like Italy, the religion is unlikely to fully support professional gender equality (Sjoberg 2004). This is because the role of women is often defined with a reference to the home rather than to professional jobs. Moreover, some studies show that in countries where a large proportion of the population is religious, the percentage of women in the market labor and in the managerial position is lower (Lehrer, 1995). This is the case of Italy where the $80 \%$ of the population is Christian.

This analysis of Italian institutions suggests that in Italy both formal and informal institutions are not supporting women to their access to managerial positions and thus to corporate boards. In this institutional framework, many legislations have been introduced to eliminate obstacles that may impede the freedom and the gender equality and help women participation to the labor market and politics. Although the Italian National Code of Equal Opportunities between Women and Men established in 2006 (called D.L. 198/2006) aims to create a legal framework that guarantees equal opportunities between women and men in all areas of society, the women inclusion in Italian corporate board is still limited. In 2008, for example, the majority of FTSE Italian companies had all-male boards and the average percentage of women on corporate boards was around $3 \%$.

Table 1. Female representation on corporate boards in 2004-2011

\begin{tabular}{|c|c|c|c|c|c|c|c|c|c|c|c|c|c|c|c|c|}
\hline & \multicolumn{2}{|c|}{2004} & \multicolumn{2}{|c|}{2005} & \multicolumn{2}{|c|}{2006} & \multicolumn{2}{|c|}{2007} & \multicolumn{2}{|c|}{2008} & \multicolumn{2}{|c|}{2009} & \multicolumn{2}{|c|}{2010} & \multicolumn{2}{|c|}{2011} \\
\hline & \# & $\%$ & $\#$ & $\%$ & $\#$ & $\%$ & $\#$ & $\%$ & $\#$ & $\%$ & $\#$ & $\%$ & $\#$ & $\%$ & $\#$ & $\%$ \\
\hline Female directors & 122 & 4.5 & 130 & 4.6 & 133 & 4.7 & 155 & 5.4 & 170 & 5.9 & 173 & 6.3 & 182 & 6.8 & 187 & 7.4 \\
\hline $\begin{array}{l}\text { Firms with at least } \\
\text { one female director }\end{array}$ & 91 & 33.8 & 97 & 35.3 & 103 & 36.4 & 118 & 39.9 & 126 & 43.8 & 129 & 46.4 & 133 & 49.6 & 136 & 51.7 \\
\hline
\end{tabular}

Source: Bianco et al., 2015. The table reports the number of female directors at the end of the year and the percentage of women director out of the total number of directors in the end of the year. We also report the number of firms with at least one female directpr and the percentage of firms with at least one woman on the board.

When present, female directors were linked through a family connection to the controlling shareholder, being the controlling shareholder herself or his wife, daughter, sister or close relative (Bianco, Ciavarella \& Signoretti, 2015). This has called for the necessity to have a legislation that helps to increase the number of nonaffiliated female directors. In 2011 a law mandated gender quotas for Italian-listed companies and for state-owned enterprises was introduced. Under the regulation on quota, starting from 2012 at least one-third of board seats must be held by directors of the less represented gender. A transition period is given to firms to help them to comply with the law. Specifically, in the first board term, at least one fifth of the board members should be female. The law is well enforced as for not complying, there is wide range of sanctions, such as: warning; fine; forfeiture of the offices of all members of the board. The aim of the law is to reduce the gender discrimination on corporate level. According to Consob (2016), looking at board characteristics after quota (between 2012 and 
2015), the entrance of the women appointed after 2012 has introduced some changes on Italian corporate boards (Table 2).

Table 2. Directors' attributes in Italian listed companies by gender

\begin{tabular}{|c|c|c|c|c|c|c|c|c|c|c|c|}
\hline & & \multirow[t]{2}{*}{ N. } & \multirow[b]{2}{*}{$\begin{array}{l}\% \\
\text { foreigner }\end{array}$} & \multirow[b]{2}{*}{$\begin{array}{l}\text { average } \\
\text { age }\end{array}$} & \multirow[b]{2}{*}{$\begin{array}{l}\% \\
\text { family }\end{array}$} & \multicolumn{2}{|c|}{ education } & \multicolumn{4}{|c|}{ professional background } \\
\hline & & & & & & $\begin{array}{l}\% \\
\text { degree }\end{array}$ & $\begin{array}{l}\% \\
\text { postgraduate } \\
\text { degree }\end{array}$ & $\begin{array}{l}\% \\
\text { managers }\end{array}$ & $\begin{array}{l}\% \\
\text { consultant }\end{array}$ & $\begin{array}{l}\% \\
\text { academic }\end{array}$ & $\begin{array}{l}\% \\
\text { other }\end{array}$ \\
\hline \multirow[t]{3}{*}{2012} & Director & 2401 & 5.0 & 57.6 & 16.2 & 84.4 & 15.3 & 76.4 & 15.4 & 8.0 & 0.2 \\
\hline & Female & 283 & 5.3 & 50.5 & 25.8 & 82.7 & 20.9 & 68.7 & 17.8 & 13.2 & 0.4 \\
\hline & Male & 2118 & 4.9 & 58.5 & 14.9 & 84.6 & 14.5 & 77.4 & 15.1 & 7.4 & 0.2 \\
\hline \multirow[t]{3}{*}{2013} & Director & 2332 & 5.7 & 57.3 & 16.3 & 84.9 & 16.5 & 75.0 & 16.4 & 8.2 & 0.5 \\
\hline & Female & 417 & 7.0 & 50.2 & 18.2 & 86.8 & 23.2 & 63.4 & 23.4 & 12.8 & 0.5 \\
\hline & Male & 1915 & 5.4 & 58.9 & 15.9 & 84.5 & 15.0 & 77.5 & 14.9 & 7.2 & 0.5 \\
\hline \multirow[t]{3}{*}{2014} & Director & 2233 & 6.0 & 57.0 & 16.2 & 84.8 & 18.0 & 72.9 & 18.6 & 8.0 & 0.5 \\
\hline & Female & 507 & 6.3 & 50.7 & 14.8 & 87.2 & 26.0 & 59.4 & 29.0 & 11.0 & 0.6 \\
\hline & Male & 1726 & 5.9 & 58.9 & 16.6 & 84.1 & 15.6 & 76.8 & 15.5 & 7.1 & 0.5 \\
\hline \multirow[t]{3}{*}{2015} & Director & 2222 & 7.1 & 56.7 & 15.8 & 85.6 & 20.5 & 70.3 & 21.2 & 8.0 & 0.5 \\
\hline & Female & 617 & 7.5 & 50.9 & 13.1 & 88.5 & 29.7 & 54.1 & 33.2 & 12.2 & 0.5 \\
\hline & Male & 1605 & 7.0 & 58.9 & 16.9 & 84.5 & 16.7 & 76.5 & 16.6 & 6.4 & 0.5 \\
\hline
\end{tabular}

Source: Consob 2016 and corporate governance reports of Italian listed companies.

Specifically, newly appointed female members have contributed to decrease the average age of directors and to increase the level of professional background. Additionally, the newly appointed female directors have increased the level of education (both the proportion of graduated and post-graduated directors has risen respectively, from about $84 \%$ to $86 \%$ and from around $15 \%$ to $21 \%$ ). These results show that the new female directors have professional experience and are on average more educated than previous female members.

This new framework calls for new research on the effect of quota on board activities. Specifically, if the quota has increased the number of female directors and the level of education and professional background on corporate board, it is not clear whether the quota has contributed to improve the board function and board structure.

\subsection{Literature Review and Hypotheses Development}

Boards are expected to perform specific functions (Zona \& Zattoni, 2007; Minichilli, Zattoni, Nielsen, \& Huse, 2012; Post \& Byron, 2015). We focus on two set of functions: (1) monitoring the firm, (2) identifying and discussing the strategy. The monitoring task is derived from the agency theory (Fama, 1980; Jensen \& Meckling, 1976), suggesting that the primary role of boards is to safeguard shareholders from management misappropriation (Shleifer \& Vishny, 1997) or minority shareholders from blockholder expropriation (Shleifer, 1986). To accomplish the monitoring task, board members should scrutinize top executives' behaviors and actively monitor firm performance (Hillman \& Dalziel, 2003).

The probability of board members merely acting as an active audience in corporate boardrooms is increasing along with the access to inside knowledge of the firm (Mallette \& Fowler, 1992). Hence, preparation for and participation in board meetings - in terms of carefully scrutinizing information provided by management before meetings, finding information regarding issues relevant to the company and actively participating during meetings with questions is a key board process affecting its monitoring. Prior study documents that, to be capable to ask questions and challenge the executives during the meetings, women prepare conscientiously for the board meetings (Izraeli, 2000; Huse \& Solberg 2006). As a minority, women has harder job to establish credibility and influencing other board members which make them more vigilant than man about preparing for the board meetings (Singh, Kumra \& Vinnicombe 2002; Huse \& Solberg, 2006). Women also are more prone than men to pick up some details and follows up from the board agenda. It is related to the fact that women embrace their fiduciary responsibilities more strongly and hence they are more likely to sit on the audit committee (Adams \& Ferreira, 2009). Also, Adams and Funk (2012) argue that the women who hold the position on board are less security, less tradition and more self-direction- and stimulation-oriented than male board members. Thus, women directors frequently ask questions so they tend not to quickly acknowledge the passed 
by executives information. Women are likely to question business practices that are unethical (Franke, Crown \& Spake, 1997) as well as tend to apply stricter ethical standards (Pan and Sparks, 2012). Boards with higher female representation are more likely to engage in constant professionalization on the job by organizing extra meetings such as orientation programs or deep dives (Brown \& Anastasopoulos, 2002). Empirical evidence confirms that firms with higher women representation on boards held more meetings, have higher attendance rates and hence engage in tougher monitoring (Adams \& Ferreira 2009). Based on the above discussions, we hypothesize that boards with higher women representation are more accountable towards shareholders hence, more diligent in their monitoring as formulated in the following hypothesis:

Hypothesis 1a: Gender diversity, measured as the percentage of women on boards, enforced by quota regulation, enhance the commitment of the boards towards corporate governance best practices in terms of board functions.

Hypothesis 1b: Gender diversity, measured as the percentage of women on boards, enforced by quota regulation, brings more accountable to shareholders and diligent monitoring, through a higher attendance and a higher numbers of board meetings.

One of the most important duties of the board through which the interests of shareholders and managers are likely to be less divergent is setting executive remuneration policy. Compensation schemes provide incentives for managers, reducing the conflicts of interests between managers and shareholders (see a survey by Murphy, 1999). Managerial remuneration is identified and monitored by the board of directors that devote careful attention to the long-term interests of the firm and its shareholders. Boards with women are more prone to transparency of the board activities such as executive remuneration policy design and monitoring. Moreover, boards with women representation are more likely to set managerial incentive schemes that include nonfinancial performance measures such as customer satisfaction, innovation and corporate social responsibility (Brown \& Anastasopoulos, 2004; Babalola, 2009). Based on these arguments, we formulate the following hypothesis:

Hypothesis 1c: Gender diversity, measured as the percentage of women on boards, enforced by quota regulation, brings more board commitment and effectiveness towards implementing and monitoring competitive and proportionate executive compensation.

The second function of the board is to identify and discuss the strategy that the firm has to follow. Boards with women on boards identify criteria for measuring strategy and monitor implementation of the strategy more often than all-male boards. Nielsen and Huse (2010) find that women on boards are positively related to the control and implementation of the strategy. Based on the above discussion, we hypothesize that boards with higher women representation have higher competences and a wider perspective of decision-making process, hence more involvement in strategic task as formulated in the following hypothesis:

Hypothesis 2: Gender diversity, measured as the percentage of women on boards enforced by quota regulation, brings more board involvement in firm strategy activities.

According to the literature, adding a woman to the board makes its composition more diverse, which affects the effectiveness of the board. Based on previous research, the number of women on top management has a positive effect on the number of female employees in the talent pipeline. According to Bernardi, Bosco and Reis (2004) show that firms with an increase in the number of female directors have a pronounced number of women ate the executive managerial level. They may influence the composition of a team. Based on this argument, we identify the following hypothesis:

Hypothesis 3a: Gender diversity, measured as the percentage of women on boards enforced by quota regulation, have a positive influence on the use of practices related to a well balanced membership of the board.

The higher percentage of women of board may influence the independent status of the board. Abbott, Parker \& Presley (2012) reveal that female directors in a sample of the US corporations are more likely to be independent than male. Bohren \& Staubo (2015) find out that after introducing quotas in Norway the board independence increased. Following this argument, we identify the following hypothesis:

Hypothesis 3b: Gender diversity, measured as the percentage of women on boards enforced by quota regulation, have a positive influence on the number of independent directors in the three main board committees, i.e. audit committee; remuneration committee and nomination committee.

According to the literature (Jackson, Ellstrand \& Daily C. 1996), female directors bring to the board table new qualities regarding their knowledge, skills, experience, attitudes, values and behavioral style (for typical gender differences and more risk-averse see Croson and Gneezy, 2009; for the effect on competition, see Niederle, 2014, and for differences with men, see Matsa and Miller, 2013). Gender diversity brings more competences on board (Østergaard, Timmermans \& Kristinsson 2011, Jehn \& Bezrukova, 2007). Moreover, research indicates that 
after the introduction of quota law that increase the number of women on corporate boards, the average age of board members decreases and the tenure decreases (Bianco, Ciaverella \& Signoretti, 2015; Consob 2016; 2017).

Following this, we state this hypothesis:

Hypothesis 3c: Gender diversity, measured as the percentage of women on boards enforced by quota regulation, reduce the average number of years of each board member has been on the board.

\section{Methodological Approach: Sample, Variables and Model}

This paper's main purpose is to determine how the introduction of quota law, and consequently the higher number of women on corporate boards, influences the board outcomes. As we mentioned above, in 2012, Italy has introduced quota for public companies and state-owned companies. Specifically, every listed company has to comply with the $20 \%$ (at least) board gender quota in the first term. Since the quota is a regulation, it can be considered to be an exogenous shock to diversity and it can help us to understand the effect of higher gender diversity on board outcomes. We test this, using an econometric model that allows us to identify the casual effect of female directors on corporate governance. For estimation, we rely on the fixed-effect estimator, which allows us to capture all time-invariant characteristics at the firm level.

Our sample includes the 40 largest Italian companies by market capitalization. The sample could seem small, but it accounts for $80 \%$ of the domestic market capitalization. We obtain corporate governance data and accounting data from the database Thomson Reuters - Datastream. Specifically, data about boards come from Datastream ASSET4 ESG database. This database provides detailed information on corporate governance, covering information on board structure such as board composition, board committees and board size, and information on board functions such as board activities and board policies. Accounting data come from Thomson Datastream Advance database.

Since our primarily interest is to test the effect of female directors before and after the quota, the coverage of our sample begins in 2008 and ends in 2015. In order to analyze the differences in board diversity, we interact the percentage of women directors with a dummy variable called "quota" (equal to 1 for the years 2012-2015).

We combine quantitative with qualitative data. Qualitative data are related to the board functions and activities. These include info about the best practice corporate governance principles used by a company, its commitment towards a competitive and proportionate management compensation policy, the company's capacity to show and communicate a strategy that integrates financial and social dimensions, the effectiveness of the board to ensure a critical exchange of ideas and an independent decision-making process. This info come from the annual corporate governance report that reports the policies and the activities of the board. We transform this qualitative information into quantitative outcomes. Specifically, we use datastream scores to measure qualitative data. Scores in Datastream are calculated by equally weighting and z-scoring all underlying data points and comparing them against all companies in the ASSET4 ESG database (Datastream Guide). Basically, scores compare one company with a given benchmark. Higher resulting percentage means a better corporate governance outcome.

The first dependent variable represents the first board function: this is firm monitoring. We use as a proxy of monitoring one of the Corporate Governance Score Category from the Datastream which is called Board Functions. It is an accumulated score derived from a number of Indicators' value from Datastream. It measures a company's management commitment and effectiveness towards following best practice corporate governance principles related to board functions. Specifically, it reflects a company's capacity to have an effective board by setting up the essential board committees with allocated tasks and responsibilities. The Category of Board Functions includes data (Indicators) on board attendance, board meeting, the presence of policies for complying with the country's corporate governance codes with regard to the board committees. We look also at the sub-Indicators to detangle the board functions. We firstly focus on two variables: board meetings and board attendance. Board Meetings measures the number of board meetings per year and the variable Board Attendance indicates whether the company publish information about the attendance of the individual board members at board meetings. Since the board meeting is a vehicle to have information, we consider these variables as proxy of the board attitude towards the monitoring function.

The second indicator that aims to identify another monitoring activity is the monitoring on executive remuneration policies. We use as a proxy the Corporate Governance Score Category that measures company's management commitment and effectiveness towards following best practice corporate governance principles related to competitive and proportionate management compensation. It reflects a company's capacity to attract and retain executives and board members with the necessary skills by linking their compensation to individual or company-wide financial or extra-financial targets, avoiding excessive and un-proportionate remuneration. 
The second board function is the board involvement in the firm strategy activities. We use as a proxy another Corporate Governance Score Category from the Datastream which is called Integrated Mission, Vision and Strategy. It measures the company's management commitment towards the creation of an overarching vision and strategy integrating financial and extra-financial aspects. It reflects board's capacity to convincingly show and communicate that it integrates the economic (financial), social and environmental dimensions into its day-to-day decision-making processes.

Our aim is to identify also the changes in board structure due to the introduction of the quota law. The Corporate Governance Score Category from the Datastream which is called Board Structure. It is measures a company's management commitment and effectiveness towards following best practice corporate governance principles related to a well balanced membership of the board. It reflects a company's capacity to ensure a critical exchange of ideas and an independent decision-making process through an experienced, diverse and independent board. The Category of Board Structure includes data (Indicators) on Corporate Governance Code policies compliance with regard to the board size, board independence, board composition, board tenure and the independence of the board committees. The variable Audit Committee independence measures the percentage of independent board members on the audit committee. The Nomination Committee independence measures the percentage of independent board members on the nomination committee. The Compensation Committee independence measures the percentage of independent board members on the compensation committee. The board tenure is measured as the average number of years each board member has been serving on the boards.

We include control variables related to board characteristics that previous studies found a significant impact. The board size and the board independence measured as the percentage of independent directors have been considered as two of the most important variables in explaining the corporate governance dynamics (Denis \& Saris, 1999; Dalton, Daily, Ellstrand \& Johnson, 1998). As proxy of firm size, we use Total Assets. All variables are reported and defined in table 3.

Table 3. Variables description

\begin{tabular}{|c|c|c|}
\hline Variable name & Label & Description \\
\hline Board Functions & $\begin{array}{l}\text { Category } \\
\text { Score }\end{array}$ & $\begin{array}{l}\text { It measures a company's management commitment and effectiveness towards following best practice } \\
\text { corporate governance principles related to board activities and functions. It reflects a company's capacity } \\
\text { to have an effective board by setting up the essential board committees with allocated tasks and } \\
\text { responsibilities. }\end{array}$ \\
\hline Board Attendance & (Score) & $\begin{array}{l}\text { Does the company publish information about the attendance of the individual board members at board } \\
\text { meetings? }\end{array}$ \\
\hline Board Meetings & (Score) & Number of board meetings per year. \\
\hline $\begin{array}{l}\text { Control over } \\
\text { compensation }\end{array}$ & (Score) & $\begin{array}{l}\text { It measures a company's management commitment and effectiveness towards following best practice } \\
\text { corporate governance principles related to competitive and proportionate management compensation. It } \\
\text { reflects a company's capacity to attract and retain executives and board members with the necessary skills } \\
\text { by linking their compensation to individual or company-wide financial or extra-financial targets. }\end{array}$ \\
\hline Strategy & $\begin{array}{l}\text { Category } \\
\text { Score }\end{array}$ & $\begin{array}{l}\text { It measures a company's management commitment and effectiveness towards the creation of an } \\
\text { overarching vision and strategy integrating financial and extra-financial aspects. It reflects a company's } \\
\text { capacity to convincingly show and communicate that it integrates the economic (financial), social and } \\
\text { environmental dimensions into its day-to-day decision-making processes. }\end{array}$ \\
\hline Board Structure & $\begin{array}{l}\text { Category } \\
\text { Score }\end{array}$ & $\begin{array}{l}\text { It measures a company's management commitment and effectiveness towards following best practice } \\
\text { corporate governance principles related to a well balanced membership of the board. It reflects a } \\
\text { company's capacity to ensure a critical exchange of ideas and an independent decision-making process } \\
\text { through an experienced, diverse and independent board. }\end{array}$ \\
\hline Audit Committee Ind & (Score) & Percentage of independent board members on the audit committee as stipulated by the company. \\
\hline Comp Committee Ind & (Score) & Percentage of independent board members on the compensation committee as stipulated by the company. \\
\hline Nomination & (Score) & Percentage of non-executive board members on the nomination committee. \\
\hline \multicolumn{3}{|r|}{ T) } \\
\hline Board Structure & $\begin{array}{l}\text { Category } \\
\text { Score }\end{array}$ & $\begin{array}{l}\text { It measures a company's management commitment and effectiveness towards following best practice } \\
\text { corporate governance principles related to a well balanced membership of the board. It reflects a } \\
\text { company's capacity to ensure a critical exchange of ideas and an independent decision-making process } \\
\text { through an experienced, diverse and independent board. }\end{array}$ \\
\hline Tenured Board & (Score) & Average number of years each board member has been on the board. \\
\hline Quota & Quota & It is a dummy equal to 1 in years from 2012 to 2015 . \\
\hline Women directors \% & $\begin{array}{l}\text { Female } \\
\text { directors }\end{array}$ & Percentage of women on the board of directors. \\
\hline $\begin{array}{l}\text { Independent } \\
\text { directors } \%\end{array}$ & $\begin{array}{l}\text { Independent } \\
\text { directors }\end{array}$ & Percentage of independent board members as reported by the company. \\
\hline Board size & Board size & The total number of board members at the end of the fiscal year. \\
\hline
\end{tabular}


The Scores are calculated by equally weighting and z-scoring all underlying data points and comparing them against all companies in Datastream. The resulting percentage is therefore a relative measure of performance, z-scored and normalized to better distinguish values and position the score between 0 and $100 \%$. A Z Score, or "standard score" expresses the value in units of standard deviation of that value from the mean value of all companies.

To investigate the effect of women after the introduction of quota, we estimate the following regression model for gender representation on the board of firm $\mathrm{j}$ :

$$
\text { CGTjt }=\beta_{1} \text { Women }^{*} \text { Quota }_{\mathrm{jt}}+\gamma_{1} * \text { Control }{ }_{\mathrm{jt}}+\varepsilon_{\mathrm{jt}}
$$

where CGTijt measures a series of corporate governance scores that proxy for board functions such as monitoring and involvement in the firm strategy at firm $\mathrm{j}$ in period $\mathrm{t}$. As discussed above, to measure the monitoring function we consider as dependent variable: (1) Board Functions Score as well as its sub-scores (2-3) (Board Meetings and Board Attendance). On the top of it we look at Compensation policy Score (4) to identify the executive remuneration monitoring. Also, we use the Strategy Score (5) to identify the board involvement in strategy-related activities. Lastly, we apply the Board Structure Score (6) and its sub-scores: (7) tenured boards; (8) audit committee independence; (9) Nomination committee independence; (10) Compensation committee independence.

To understand the differences in the effect of women, we use the interaction term Women*quota. This variable is the interaction between the percentage of women directors on a company's board and a dummy variable equal to 1 for the years 2012-2015. The coefficient measures the differences before and after the quota, so it allows to capture changes in corporate governance outcomes when the number of women increases due to quota regulation.

\section{Results}

The regression results show that introducing regulation on quota matters for the board functions (table 4). The impact of the quota on the relationship between board functions and women presence on board is positive and statistically significant, indicating that the use of governance practices that follow the corporate governance guidelines has increased after the law. Specifically, the difference in the effect of female directors after the quota is $30 \%$ higher than before the introduction of law (column 1). The hypothesis 1a has been confirmed. We also report that board function enhances with the size of the board. The variable borad size is positive and statistically significant. Larger boards potentially bring more experience and knowledge (Dalton, Daily, Johnson, \& Ellstrand, 1999) and hence, have better resources to enhance board functions.

As we look at the specific sub-scores of the Board Functions Score and we find that all the measures: board attendance (column 2), board meetings (column 3) and control over compensation (column 4) are statistically significant. Specifically, the effect of women after the introduction of quota on board attendance is of highest magnitude (0.43). This result suggests that after the introduction of quota law, the women are more diligent in attending the board meetings. This could be interpreted that the women on boards before the introduction of quota regulation, most of them family-connected to the founder and the CEO of the firms, were less prone to attend board meeting (Bianco, Ciavarella \& Signoretti 2015). Our results bring evidence that due to the quota enforcing more active women are elected. The quota has positive effect on the relationship between ratio of women on boards and the number of board meetings. Board meetings are a fundamental source of inside firm information for directors (Adams and Ferreira, 2009). Hence, the higher their number, the more relevant information the board members can acquire and can better perform their function and the role within firm. After the introduction of quota law, the female directors have a positive influence on the number of board meetings. Board meetings and board attendance are two proxies that help to identify the attitude of the boards of having information about the firms, and hence be more prone towards the monitoring function. The findings from this analysis provided consistent support for our Hypotheses 1b, suggesting that women after quota enhance the commitment of the board towards a better monitoring function.

Interestingly, the effect of quota on the relationship between women presence on boards compensation policy score (column 4) is negative and statistically significant. Adding one more woman to the board after the regulation is binding causes decrease of the company's management commitment and effectiveness towards following best practice corporate governance principles related to competitive and proportionate management compensation by 5.44. Our hypothesis $1 \mathrm{c}$ has not been confirmed. One possible explaination could be the role of women on board committees. Adams and Ferreira (2009) show that women are less likely to sit on compensation committees than men are and thus have less involvement in setting CEO pay. Also, boards with higher women representation tend to compensate directors with more equity-based compensation that is more aligned with the shareholder interests and results most often in higher executive pay level. 
Column 5 presents there is a positive relationship between women board representation and the extent to which board engages in firm strategy related activities. Post regulation including one more women to the board brings in increasing in Strategy Score (column 5) that is a proxy for board involvement in firm strategic activities. This result shows that after the quota, the higher percentage of women has improved the strategy task. This result support Hypothesis 2. This finding is consistent with the literature. Recent studies show that female directors positively influence firm performance through their involvement in corporate strategy (Levi et al, and Post \& Byron 2016). We also report evidence that the board engagement in strategy depends on the board independence. The variable independent directors is positive and statistically significant. Independent directors are board members with no affilitiation with the company. Since their role is to bring an outside persective and protect stakeholders' interests, they contribute to increase the board committment towards strategies that include financial and social dimensions.

Table 4. The effect of quota on the board functions

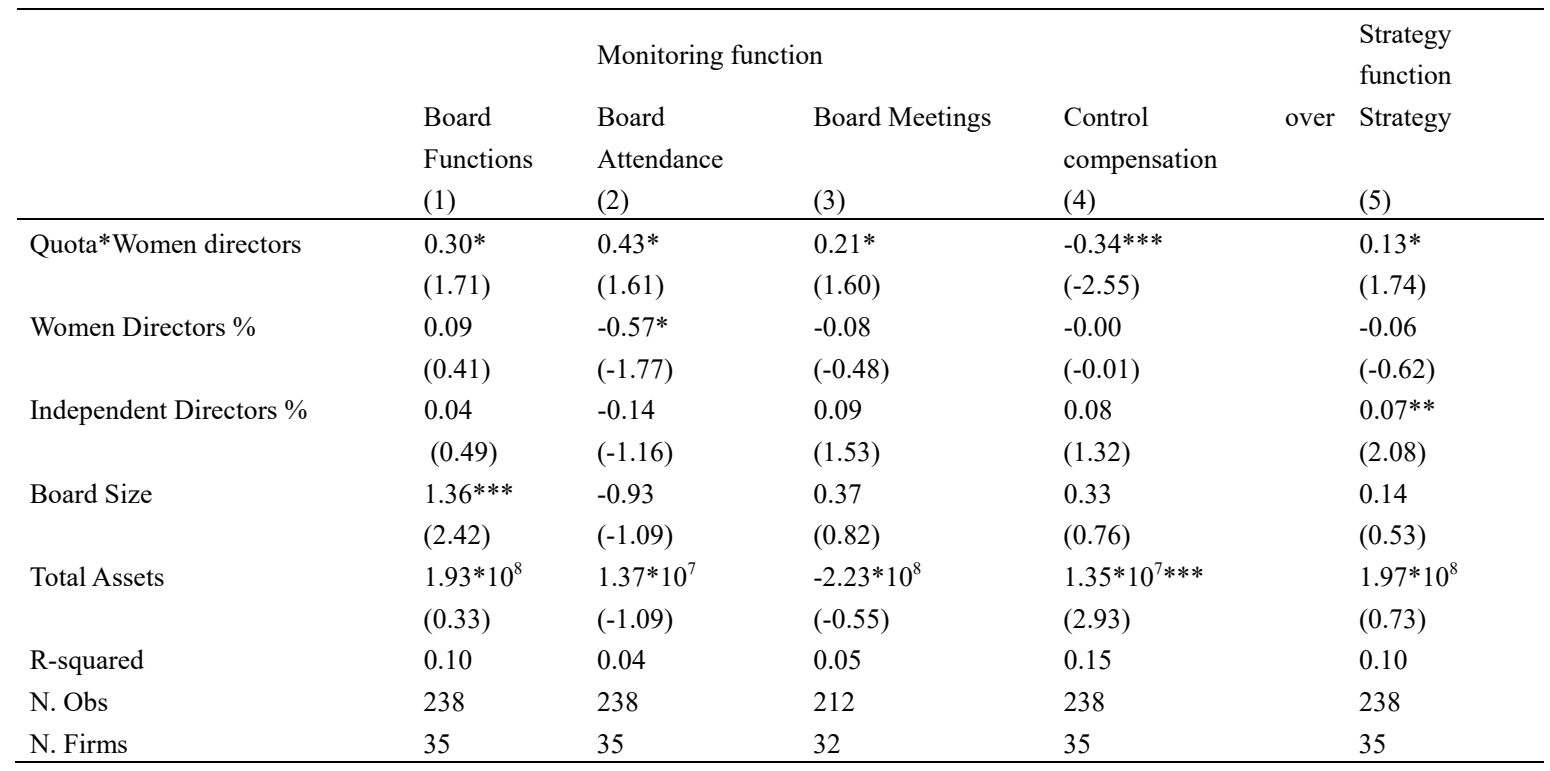

T-statistics are reported in brackets. $* * *$ and $* * *$ denotes significance at $10 \%, 5 \%$ and $1 \%$ respectively

Table 5 reports the effect of female director after quota on board structure. We did not find any statistically significant relation between Board Structure Score and interaction term between quotas and women on boards. This result does not support our hypothesis 3a, that expects a positive effect of women on the use of well-balanced policies. We document that the variable board structure is affected positively by the board independence. Prior studies confirm that independent board members are better equipped to discipline executives, as they are expected to limit opportunistic behavior, thereby reducing the agency problem (Hermalin \& Weisbach, 1998; Ryan \& Wiggins, 2004; Pathan, 2009). We report evidence that independent directors contribute to the capacity of the board to ensure a critical exchange ideas and an independent decision-making process.

Looking at the effect of women after quota regulation on the independence of the three main committees, we report evidence that women after quota have a significant impact on Audit Committee independence. We do not find statistical difference in the independence of nomination committee and compensation committee. The hypothesis $3 \mathrm{~b}$ is partially supported. This may suggest that after the introduction of quota, women are less likely to be appointed in the nomination and compensation committee. Adams \& Ferreira (2009), and Rhode \& Packel (2014) argue that women, being not part of the old boys' club, can be excluded to the powerful committees. This may be an explaination of our not significant results.

Table 5. The effect of quota on board structure

\begin{tabular}{|c|c|c|c|c|c|c|}
\hline & $\begin{array}{l}\text { Board } \\
\text { Structure } \\
(6)\end{array}$ & $\begin{array}{l}\text { Tenured Board } \\
\text { (7) }\end{array}$ & $\begin{array}{l}\text { Audit } \\
\text { Ind } \\
(8)\end{array}$ & Committee & $\begin{array}{l}\text { Nomination } \\
\text { Committee Ind } \\
\text { (9) }\end{array}$ & $\begin{array}{l}\text { Compensation } \\
\text { Committee Ind } \\
\text { (10) }\end{array}$ \\
\hline Quota*Women Directors & -0.10 & 0.01 & $0.15^{*}$ & & 0.04 & 0.20 \\
\hline
\end{tabular}




\begin{tabular}{llllll}
\hline & $(-0.72)$ & $(0.06)$ & $(1.72)$ & $(0.21)$ & $(1.27)$ \\
Women Directors \% & 0.18 & -0.19 & -0.13 & $(-0-07)$ & 0.22 \\
& $(1.06)$ & $(-0.77)$ & $(-1.17)$ & $(-0.28)$ & $(1.13)$ \\
Independent Directors \% & $0.28^{* * *}$ & 0.03 & $0.10^{* * *}$ & $-0.14^{*}$ & $0.28^{* * *}$ \\
& $(4.32)$ & $(-1.50)$ & $(2.53)$ & $(-1.50)$ & $(3.87)$ \\
Board Size & $-1.09^{* * *}$ & 0.41 & 0.26 & 0.34 & -0.59 \\
& $(-2.43)$ & $(-1.50)$ & $(0.90)$ & $(0.52)$ & $(-1.18)$ \\
Total Assets & $2.63 * 10^{9}$ & $1.34 * 10^{7 * *}$ & $6.29 * 10^{8 * *}$ & $7.98^{*} 10^{8}$ & $1.22^{*} 10^{8}$ \\
& $(0.06)$ & $(2.30)$ & $(-2.09)$ & $(1.31)$ & $(0.23)$ \\
R-squared & 0.25 & 0.10 & 0.07 & 0.02 & 0.21 \\
N. Obs & 238 & 120 & 237 & 171 & 226 \\
N. Firms & 35 & 25 & 35 & 27 & 33 \\
\hline
\end{tabular}

T-statistics are reported in brackets. ${ }^{*}, *$ and $* * *$ denotes significance at $10 \%, 5 \%$ and $1 \%$ respectively.

\section{Conclusion}

In preparation of implementing the Directive of the European Parliament and of the Council on improving the gender balance among non-executive directors of companies listed on stock exchanges and related measures, several governments across Europe have adopted quotas to increase gender diversity on corporate boards, among them Italy. This paper studies the effects of quota for female board representation introduced in Italy 2012. Within five years, the female share of corporate directorships increased from $4,6 \%$ in 2010 to $25.80 \%$ in 2015 (Velkova, 2015). Using quantative-qualitative data from Datastream for publicly listed firms in Italy we find that the effect of quota for women on boards is positive and significant for the monitoring function and for the board involvement in strategy. Specifically, our research demonstrates that a higher percentage of women on corporate boards after introducing law on quotas in Italy leads to better attendance, more board meetings, and thus improves board monitoring. We also document that after the introduction of quota, women are more involved in the decisions related to the firm strategy that combine financial and social dimensions. This suggests that an higher inclusion of women on corporate boards contribute to have a more comprehensive perspective that combines financial and non-financial aspects. However, when we test the effect of women on the use of well-balanced policies we do not report statistically significant results. This means that there are no differences in the use of such policies before and after the quota implementation. The number of women after 2012 has a positive influence on the audit committee independence. This committee is responsible for the monitoring on the financial reporting process, the selection of the auditors and the evaluation of audit results. This shows that the new women have increased the audit committee independence, suggesting an increasing contribution on the monitor over the financial reporting.

Our results indicate important implications for policy makers. First, the mandatory increase in the number of women on corporate boards contributes to enhance the board activities, making the boards more enganged in monitoring and strategizing. This is a benefit that help to have a better corporate governance and, consequently, better firm decisions.

Second, the new legislation has contributed to introduce a new "type" of women elected. These women are more active and deligent than before. One explaination could be related to the selection process. The new women may be more competent and prepared than before when then usually were appointed by families in family-owned firms. This paper provide evidence that restrictive law on gender parity in the form of quota in the Southern European countries with non-supportive institutional settings for women career advancement increases the boards expertise and diligence, thus board effectiveness.

We also acknowledge some limitation of the study and directions for future research. First, there is a need to properly understand the role of institutions in supporting women presence on the labor market, and thus their readiness and position on boards in Italy. Formal and informal institutions have impact on women's choices. While the literature provides some evidence in the individual impact of selected institutions on women's propensity in the participation in the upper echelon (Grosvold, Rayton, Brammer, 2016), the supportive or ono-supportive effect that is produced by interaction of different country-specific institutional matrix is still poorly understood.

Second, future research could enhance the understanding on the role of institutional environment on the women's representation in the upper echelon. It would be interesting to examine how the country-level institutions influence the effectiveness of gender board quotas in ensuring gender equality in the boardroom and executive 
teams. Most studies refer to the Nordic countries, predominately Norway, that have a long history of social support for gender equality. There is necessity to look at the institutional support to women in career in countries where it has been traditionally very low.

\section{References}

Abbott, L., Parker, S., \& Presley, T. (2012). Female Board Presence and the Likelihood of Financial Restatement. Accounting Horizons, 26(4), 607-629. https://doi.org/10.2308/acch-50249

Adams R. B., (2016). Women on boards: The superheroes of tomorrow? The Leadership Quarterly, 27(3), 349-536. https://doi.org/10.1016/j.leaqua.2015.11.001

Adams, R. B., \& Funk, P. C. (2012). Beyond the glass ceiling: Does gender matter? Management Science, 58(2), 219-235. https://doi.org/10.1287/mnsc.1110.1452

Adams, R., \& Ferreira, D. (2009). Women in the boardroom and their impact on governance and performance, Journal of Financial Economics, 94(2), 291-309. https://doi.org/10.1016/j.jfineco.2008.10.007

Aguilera, R., \& Cuervo-Cazurra, A. (2004). Codes of good governance worldwide: What is the trigger?. Organization Studies, 25, 415-443. https://doi.org/10.1177/0170840604040669

Aguilera, R., \& Jackson, G. (2003). The cross national-diversity of corporate governance. Dimensions and determinants. Academy of Management Review, 28, 447-465. https://doi.org/10.2307/30040732

Aguilera, R., Filatotchev, I., Gospel, H., \& Jackson, G. (2008). An Organizational Approach to Comparative Corporate Governance: Costs, Contingencies, and Complementarities. Organization Science, 19(3), 381-495. https://doi.org/10.1287/orsc.1070.0322

Babola, S. (2009). Women entrepreneurial innovative behaviour: The role of psychological capital. International Jounral of Business and Management, 4(11), 184-192. 10.5539/ijbm.v4n11p184

Bernardi, R. A., Bosco, S. M., \& Reis, K. M. (2004). Corporate leardeship in the Fortune 500: Women in executive management postitions. Journal of Business and Economics Research, 2(12), 1-10.

Bianco, M., Ciavarella, A., \& Signoretti, R. (2015). Women on Corporate Boards in Italy: The Role of Family Connections. Corporate Governance: An International Review, 23,129-144. https://doi.org/10.1111/corg.12097

Bøhren, Ø., \& Saubo, S. (2015). Mandatory Gender Balance and Board Independence. European Financial Management, 10, 1-28. https://doi.org/10.1111/eufm.12060

Budig, M., Misra, J., \& Boeckmann, I. (2012). The Motherhood Penalty in Cross-National Perspective: The Importance of Work-Family Policies and Cultural Attitudes. Social Politics, 19(2), 163-193. https://doi.org/10.1093/sp/jxs006

Burke, R. (1995). Do women directors on corporate boards make the difference? View from women directors. Corporate Governance: An International Review, 3, 138-145. https://doi.org/10.1111/j.1467-8683.1995.tb00109.x

Burke, R. (1997). Women directors: Selection, acceptance and benefits for board membership. Corporate Governance: An International Review, 5, 118-125. https://doi.org/10.1111/1467-8683.00052

Calori, R., Lubatkin, M., Very, P., \& Veiga, J. F. (1997). Modelling the Origins of Nationally-Bound Administrative Heritages: A Historical Institutional Analysis of French and British Firms. Organization Science, 8(6), 681-696. https://doi.org/10.1287/orsc.8.6.681

Carli, L. L., \& Eagly, A. H. (2011). Gender and leadership. In Bryman A, Collinson DL, Grint K, Jackson B, Uhl-Bien M. (Eds.), Handbook of Leadership. The SAGE Publications Ltd.

Catalyst. (2004). The Bottom Line; Connecting Corporate Performance and Gender Diversity. New York: Catalyst Publication.

Consob. (2016). Report on Corporate Governance of Italian companies.

Consob. (2017). Report on Corporate Governance of Italian companies.

Daily, C., Certo, T., \& Dalton. (1999). A decade of corporate women: some progress in the boardroom, none in the executive suite. Strategic Management Journal, 20, 93-99. https://doi.org/10.1002/(SICI)1097-0266(199901)20:1<93::AID-SMJ18>3.0.CO;2-7

Dalton, D., Daily, C. M., Ellstrand, A., \& Johnson, J. L. (1998). Meta-analytic reviews of board composition, 
leadership structure, and financial performance. Strategic Management Journal 19(3), 269-290. https://doi.org/10.1002/(SICI)1097-0266(199803)19:3<269::AID-SMJ950>3.3.CO;2-B

Dalton, D., Daily, C., Johnson, J., \& Ellstrand, A. (1999). Number of Directors and Financial Performance: A Meta-Analysis. The Academy of Management Journal, 42(6), 674-686. https://doi.org/10.2307/256988

Franke, G. R., Crown, D. F., \& Spake, D. F. (1997). Gender differences in ethical perceptions of business practices: A social role theory perspective. Journal of Applied Psychology, 82, 920-934. http://dx.doi.org/10.1037/0021-9010.82.6.920

Grosvold, J., \& Brammer, S. (2011). National institutional systems as antecedents of female board representation: an empirical study. Corporate Governance: An International Review, 19(2), 116-136. https://doi.org/10.1111/j.1467-8683.2010.00830.x

Grosvold, J., Rayton, B., \& Brammer, S. (2016). Women on corporate boards: a comparative institutional analysis. Business \& Society, 55(8), 1157-1196. https://doi.org/10.1177/0007650315613980

Houseknecht, S. K., \& Sastry, J. (1996). Family "decline" and child well-being: A comparative assessment. Journal of Marriage and Family, 58(3), 726-739. https://doi.org/10.2307/353732

Huse, M. (2008). Women directors and the black box of board behavior. In Vinnicombe S., Singh V., Burke R., Billimora D., Huse M (Eds.), Women on corporate boards of directors: international research and practice. Cheltenham, Edward Elgar.

Huse, M., \& Solberg, A. G. (2006). Gender-related boardroom dynamics: how Scandinavian women make and can make contributions on corporate boards. Management Review, 21(2), 113-130. https://doi.org/10.1108/09649420610650693

Izraeli, D. (2000). Women Directors in Israel. In R. Burke and M. Mattis (Eds.), Women on Corporate Boards of Directors: International Challenges and Opportunities. Kluwer: Dordrecht, The Netherlands.

Jackson, J., Ellstrand, A., \& Daily, C. (1996). Boards of directors: A review and research agenda. Journal of Management, 22, 409-438. https://doi.org/10.1016/S0149-2063(96)90031-8

Kanter, R. M. (1977). Men and women of the corporation. New York: Basic Books

Lending, C. C., Vähämaa, E. (2016). European board structure and director expertise: The impact of quotas, Research in International Business and Finance, Elsevier, 39, 486-501. https://doi.org/10.1016/j.ribaf.2016.09.004

Minichilli, A., Zattoni, A., Nielsen, S., \& Huse, M. (2011). Board task performance: An exploration of microand macro-level determinants of board effectiviness. Journal of Organizational Behavior, 33, 193-215. https://doi.org/10.1002/job.743

Minichilli, A., Zattoni, A., Nielsen, S., \& Huse, M. (2012). Board task performance: An exploration of microand macro-level determinants of board effectiviness. Journal of Organizational Behavior, 33, 193-215. https://doi.org/10.1002/job.743

Nielsen, S., \& Huse, M. (2010). The contribution of women on boards of directors: Going beyond the surface. Corporate Governance: An International Review, 18(2), 136-148. https://doi.org/10.1111/j.1467-8683.2010.00784.x

Østergaard, C. R., Timmermans, B., \& Kristinsson, K. (2011), Does a different view create som e-thing new? The effect of employee diversity on innovation. Research Policy, 40(3), 500-509. https://doi.org/10.1016/j.respol.2010.11.004

Parboteeah, K., Hoegl, M., \& Cullen, J. B. (2008). Managers' Gender Role Attitudes: A Country Institutional Profile Approach. Journal of International Business Studies, 1-19. https://doi.org/10.1057/palgrave.jibs. 8400384

Post, C., \& Byron, K. (2015). Women on boards and firm financial performance: A meta-analysis. Academy of Management Journal, 58(5), 1546-1571. https://doi.org/10.5465/amj.2013.0319

Post, C., \& Byron, K. (2016). Women on Boards of Directors and Corporate Social Performance: A Meta-Analysis. Corporate Governance: An International Review, 24(4), 428-442. https://doi.org/10.1111/corg.12165

Roe, M. (2003). Political determinants of corporate governance: Political context, corporate impact. Oxford: Oxford University Press. 
Sheridan, A. (2001). A view from the top: women on the boards of public companies. Corporate Governance: The international business and society, 1(1), 8-15. https://doi.org/10.1108/EUM0000000005456

Sheridan, A., \& Milgate, G. (2005). Accessing Board Positions: a comparison of female and male board members' views. Corporate Governance: An International Review, 13(6), 847-855. https://doi.org/10.1111/j.1467-8683.2005.00475.x

Singh, V., \& Vinnicombe, S. (2004). Why so few women directors in top UK boardrooms? Evidence and theoretical explanations. Corporate Governance: An International Review, 12(4), 479-488. https://doi.org/10.1111/j.1467-8683.2004.00388.x

Singh, V., Kumra, S., \& Vinnicombe, S. (2002). Gender and impression management: Playing the promotion game. Journal of Business Ethics, 37, 77-89. https://doi.org/10.1023/A:1014782118902

Terjesen, S., Sealy, R., \& Singh, V. (2009). Women Directors on Corporate Boards: A Review and Research Agenda. Corporate Governance: An International Review, 17(3), 320-337. https://doi.org/10.1111/j.1467-8683.2009.00742.x

Thomson, P., Graham, J., \& Lloyd, T. (2005). A woman's place is in the boardroom. London Palgrave Macmillan.

Westphal, J. D., \& Milton, L. P. (2000). How Experience and Network Ties Affect the Influence of Demographic Minorities on Corporate Boards. Administrative Science Quarterly, 45(2), 366-398. https://doi.org/10.2307/2667075

Westphal, J. D., \& Stern, I. (2007). Flattery will get you everywhere (especially if you are a male Caucasian): How integration, boardroom behaviour, and demographic minority status affect additional board appointments at U.S. companies. Academy of Management Journal, 50(2), 267-288. https://doi.org/10.2307/20159854

Zelechowski, D., \& Bilimoria, D. (2004). Characteristics of women and men corporate inside directors in the US. Corporate Governance: An International Review, 12(3), 337-342. https://doi.org/10.1111/j.1467-8683.2004.00374.x

Zona, F., \& Zattoni, A. (2007). Beyond the black box of demography: board process and task effectiveness within Italian firms. Corporate Governance: An International Review, 15(5), 852-864. https://doi.org/10.1111/j.1467-8683.2007.00606.x

\section{Copyrights}

Copyright for this article is retained by the author(s), with first publication rights granted to the journal.

This is an open-access article distributed under the terms and conditions of the Creative Commons Attribution license (http://creativecommons.org/licenses/by/4.0/). 